\title{
THE EFFECT OF PRELIMINARY DATA ON PSYCHOLOGICAL SELECTION AND POLICEWOMEN SCHOOL FOSTER OFFICERS ON THE SUCCESS OF ESTABLISHING THE CHARACTERISTICS OF “KEBHAYANGKARAAN" OF POLICEWOMEN SCHOOL STUDENTS
}

\author{
Frinsiska Pasaribu \\ Indonesian Police Science College frinsiskapasaribu71@gmail.com
}

Citation : Pasaribu, Frinsiska, The Effect of Preliminary Data on Psychological Selection and Policewomen School Foster Officers on the Success of Establishing the Characteristics of "Kebhayangkaraan" of Policewomen School Students, Management Technology and Security International Journal, pages: 30-50

Received on 5 June 2020, Accepted on 09 July 2020, Published on 1 August 2020

\begin{abstract}
The research examines the factors influencing the establishment of "kebhayangkaraan" "character of female students. The research is conducted to 47 students, with multiple linear regression analysis using the SPSS 19 program. Normality test supports the prediction of an influence between variables with the results of hypothesis testing; 1). The character of "kebhayangkaraan" of policewomen school students is positively but not significantly influenced by the results of the preliminary data on psychological selection, meaning that the initial data results of the psychological evaluation of the character of "kebhayangkaraan" cannot increase significantly this preliminary results because the psychological selection can be studied patterned and the final result of psychological selection data there is a tendency forced gets a " $\mathrm{C}$ " value even though it is given a " $\mathrm{K}$ and $\mathrm{KS}$ " value. Thus, hypothesis 1 is rejected. 2) The positive and significant "kebhayangkaraan" character is supported by the guidance of fostering counselling with a coefficient of $66.5 \%$, where the most dominant composition is able to understand the most influential being able to change mood with a coefficient of $34.1 \%$, meaning helps foster counselling support so that the character of "kebhayangkaraan" can increase. Thus, hypothesis 2 is accepted. 3) The character of "kebhayangkaraan" is influenced by guidance and foster counselling and data from the initial results of the simultaneous and significant assessment with a coefficient of $41 \%$, meaning that supports and data counselling initially results supported by the character. It is expected that through this research can provide input for the development of women's police school, especially regarding the provision of appropriate treatment to students, so students can show the character of "kebhayangkaraan."
\end{abstract}

Keywords: preliminary data, psychological selection results, character establishment counselling guidance

${ }^{1}$ Kebhayangkaraan is a character consisting of values; faith, loving the motherland, democratic, discipline, hard work, smart work, professional, simple, empathy, honest, impartial, model, and integrity. 


\section{INTRODUCTION}

\subsection{Background}

Being a police officer is a noble profession as well as a respected profession that provide protection and protection to the community, and services are needed by the community. The police force is an agency that has and implements a code of ethics and has political autonomy to control its own destiny. A police officer profession has strict standards for entry requirements, and is an organization that develops itself a theoretical knowledge. The strictness of the standard requirements for the admission to become a member of the Indonesian National Police (Polri) makes the police profession increasingly one of the most popular professions. Various requirements must be met by a person if she or he wants to become a member of Polri.

General requirements for registering as a member of Polri are Indonesian citizens; faith and piety to God the Almighty; loyal to the Unitary Republic of Indonesia based on Pancasila and the 1945 Constitution of the Republic of Indonesia; the lowest level of education is high school or equivalent; the lowest age is 18 years (when he is appointed as a member of Polri); physically and mentally healthy (showed by health certificate from a health institution); never been convicted of a crime; authoritative, honest, fair and behaves without reproach; and pass the education and training for the establishment of members of the Police.

In addition to general requirements, there are also administrative requirements that must be met, among others, following and passing the examination/testing with knockout system, including initial administrative examination material; stage I medical examination; psychological examination and testing; phase II health examination; physical safety testing; final administrative inspection; academic testing; general knowledge, Indonesian language; and English.

If they are declared passed, then the prospective students are required to attend a establishment education. Based on the decree of the Chief of Polri Number 14/2015 concerning Polri Education System, Article 1 Number 13 states that establishment education (diktuk) is an education that forms and equips students to become civil servants in Polri.

Article 13, more specifically, regarding the education for policewomen from Non-Commissioned Officer (NCO), based on the Chief of Polri Regulation $14 / 2015$, states that the education processes of NCO Policewomen is held at Policewomen School also know as "Wiyati Putri Bhayangkara." The school educates, forms, and forges the generation of "Pancasila" Enforcement. Policewomen School also organizes education for the establishment of NCO Police women and professional, proportional, transparent and accountable development of policewomen specialization.

The expected outputs of Indonesian Policewomen School, based on Article 1 of the Regulation of Polri Chief Number 20/2007 concerning Education Component Standards for Establishment Education and Development Education in Polri Education and Training Institution Institution, are policewomen that are able to show attitudes and behaviour that are in accordance with the Indonesian Police's Code of Ethics. They are devoted to God the Almighty and virtuous by upholding the law and human rights in carrying out their duties; understand and be able to apply the knowledge and technical and tactical skills of certain police tasks; and have the readiness in carrying out various tasks of police.

These attitudes and behaviours are explained in more detail in the 12 characters of kebhayangkaraan namely: faith, loving the motherland, democratic, discipline, hardwork and smart, professional, simple, empathetic, honest 
and sincere, impartial, model and integrity.

In order to realize this, we need a form of care in the form of guidance, counselling, and habituation carried out regularly and continuously by foster officers to students in the policewomen school. In a process of nurturing, it is absolutely necessary to have a psychological support that aims to help the process of forming mental personality through providing input, to participate in psychological parenting activities, and to deal with problem of the students. These provisions are regulated in Article 2 of the Regulation of Polri Chief Number 2/2007 concerning Psychological Support in the Care of Students of Polri.

The current pattern of care is very dependent on psychological support to divide or group care patterns with different treatments in each treatment group. Based on Article 9 of the Polri Chief Regulation Number 2/2007, the treatment of students as an impact of the utilization of preliminary psychological test data, including students who are classified as Good, can be directed to realize the potentials they have by involving students in student organization activities and the development of special talents. For students who are classified medium can be directed to achieve achievement by facilitated by caregivers. While students, who are classified as lacking, can be directed to help students recognize themselves and raise

their weaknesses into a positive thing. With this data, caregivers will carry out parenting assignments according to the grouping of treatment of students in order to develop the character of happiness from policewomen school students. In order to be a person of character means to be the best person. Therefore, growing in the sort of character means the person grows with the ethical potential and intellectual potential of each. Understanding this method, work ethic and competence are not something separate from human character, but both are part of one. Therefore, it takes hard work to develop one's talents so that they can be used to make a positive difference in the social environment. So as to become a school of character which in this case is women's police school, policy advocates must be equally committed to two major goals, namely: intellectual excellence and moral excellence through character education.

It is unexpected that if you look at the psychogram data in the form of preliminary data from the admission selection of the problematic students, most of the students get good grades for psychology. Whereas students who scored less during the psychological selection, they are currently on average show a good performance and even very good at policewomen school so that the growing character of "Kebhayangkaraan" are attached to the souls of these students.

\subsection{Formulation of the problem}

Based on the background description of the researchers formulated the problem, namely "Does the preliminary data from the results of psychological selection and foster officer counselling guidance have a positive and significant effect on the success of establishing the character of policewomen school students' happiness?" Furthermore, in order to be able to solve the problems that have been formulated, there is several research problems related to the problem to be examined, namely as follows:

a. Does the preliminary data from the results of psychological selection have a positive and significant effect on the successful establishment ofcharacter of "Kebhayangkaraan" of the policewomen school students?

b. Does foster officer counselling have a positive and significant effect on the successful establishment of character 
of "Kebhayangkaraan" of the policewomen school students?

c. Do the preliminary data from psychological selection and foster officer counselling guidance have a positive and significant effect on the successful establishment of character of "Kebhayangkaraan" of policewomen school student?

\section{LITERATURE REVIEW}

\subsection{Theory of Human Resources Management}

Panggabean (2004:15) states that human resource management is management related to the management of human resource empowerment activities. Sutrisno (2009:3) states that human resource management a strategic field of organization. Human resources management must be seen as an extension of the traditional view to manage people effectively and for that requires knowledge about humans and the ability to manage them. Mangkunegara (2013:2) further explains that human resource management is as a management and utilization of resources that exists in individuals. Human resources management can also be an activity of planning, procurement, development, maintenance, and the use of human resources to achieve goals, both individually and organizationally. The human resource management function is explained by Sutrisno (2009: 8-10), namely: Planning, Organizing Direction and Procurement, Control, Development, Compensation, Integration, Maintenance, Discipline, and Retired.

\subsection{Guidance and Counselling Theories}

The Directorate General of Education Quality Improvement and Education personnel and the Ministry of National Education in 2007 (in Retnaningdyastuti and Ajie, 2013)

$$
\text { suggested that the }
$$
guidance service is one of the basic guidance services designed to require counsellors to make a direct contact with students in the classroom on a scheduled basis, the counsellor provides this guidance service to learners. Guidance services are different from teaching.

Luddin (2010: 11-12) states that guidance and counselling is a translation of guidance and counseling in English. The meaning of the two terms can only be captured correctly when reviewed what is meant by the two original words in English. In the English dictionary, guidance is associated with the word origin guide, which is interpreted as leading the way (showing the way), leading, guiding (conducting), giving instructions, regulating, directing (governing), and giving advice. Meanwhile, counselling is associated with the word counsel which is interpreted as advice (to obtain counsel), advice (to give counsel), talks (to take counsel) so that counselling will be interpreted as giving advice and talking with exchanging ideas. The indicators of guidance and counselling, according to Prayino, et. al., (in Luddin, 2010: 4) are as follows:
a. Accept yourself.
b. Get to know and accept the environment positively and dynamically.
c. Direct yourself effectively and productively in planning for a better life in the future.


A study related to psychology and counselling was carried out by Tas'a in 2011, titled "The Urgency of Psychological Tests in Placement and Distribution Services in High Schools." With regard to majors in high school, where each student will be placed in a particular department that matches their abilities, so it is expected that students who are placed in certain majors can complete their studies by not finding many difficulties. For that direction majors must be done properly and correctly.

This study seeks to explore deeper into the urgency of psychological testing in placement services in high school. Based on research results it is known that psychological testing as a tool to measure the ability or potential possessed by someone, is very important to be used in positioning or placing a person in a particular place that can not only be used in majors, but for the selection of recruitment of employees and candidates students at a certain level. Psychological tests are even used for kindergarten children who will enter elementary school. By utilizing the results of psychological tests in the major's activities in high school turned out to provide many benefits to students. Difficulties that are felt when participating in the learning process may not be felt too much anymore, because the placement made is based on the potential that has according to interests, talents by not ignoring the learning outcomes obtained.

\subsection{Character Building Theory}

The word 'character' comes from the Greek 'karasso' meaning blueprint, basic format, fingerprints, such as fingerprints (Koesoema, 2007:90). Mounier sees character in two approaches: (1) as a collection of conditions that are given away, which already exist; and (2) as a desired process, built in the future (Koesoema, 2007:90-91). In this context, character is seen as an attitude that already exists in students and that must be developed in the future. Character is the same as attitude. Character or attitude is a mixture of all human nature that is fixed, so it becomes a special sign to distinguish one person from another. According to $\mathrm{Ki}$ Hadjar Dewantara (in Marzuki and Khanifah, 2016:177), character occurs because of the basic development that has been affected by the teaching. So, there is an element of talent that children have and an element of further education. Inwardly, character can be said to be a constant counterpart between one's inner life and the actions of birth. Then the development of a person's character depends on the initial talent and the influence of education experienced later, so that it becomes a permanent character in that person. In character education it is very important to pay attention to aspects, talent and education.

Driyarkara (2006:488-494) equates character with attitude. According to Driyarkara, someone is said to have a character or an attitude if he has the habit of defeating impulses that are not good in him. Or positively, people have a habit of doing good encouragement. In character education, good talents are developed so that they dominate the life of the person. The initial talent must be developed so that the character becomes good. The element of education is very important to build someone's character.

From some of the above meanings, character can be said simply as positive values and attitudes of life, which a person has so that it influences the 
person's behaviour, way of thinking and acting, and eventually becomes his character. For example, honesty. A honest attitude affects a person in his whole life, especially in dealing with life problems, both personal lives, living with others, and also in his work. In other words, good attitude has become a habit of his life. So if people are said to be disciplined, in most of their lives, they are indeed disciplined. People are said to have the character of respect for others when in their minds, in their attitudes, and in dealing with others, they do respect the person of others.

Subagyo's study (2013), titled "A Portrait of Historical Education at Indonesian National Police Academy for Character Building for Civil Police" aims at describing the implementation of historical education for the Police Academy cadets and various problems that occur. Research data are collected from curriculum documents and informal learning planning. The data collection techniques are document studies and interviews and the data analysis technique is interactive analysis. The results showed that the hours of study for historical education were only a small part of the education process at the Police Academy, so that the material could not be absorbed optimally and could less influence the establishment of a civilian police character.

\subsection{Definition of Character Education}

Character education means education that aims to help students experience, acquire, and possess the desired strong character. For example, if you want a honest character to occur, then character education means that this effort helps students so that the value of honesty belongs to them and becomes a part of their lives that affects all ways of thinking and acting in their lives. Finally, it is hoped that honesty will become his character in his life everywhere. Character education is carried out with the belief that a person's character can be developed and can be changed. From the notion of character that contains elements of innate talent and the influence of education, it is clear here that everyone must have confidence that a person's character and character can be developed and changed. The character of students who are initially not good, through education can be helped to be reduced and eventually changed to be good. Educators here must not be discouraged if they see students who are not of good character. One of the tasks as educators is to help them to change and develop into good.

Driyarkara (2006:488-494) explains that a person's character is good and bad. The task of education is to develop characters that are already good and help eliminate bad characters in students. Thus, in students they only develop good character. Driyarkara emphasized as a human person that they should not only follow their innate talents, but must be brave to develop and change if they are not good. A person's character is influenced by the initial talent and subsequent teaching, or the student's initial talent and education that influence the next. This means that character education needs to pay attention to one's innate talent. Here Educators need to look at the qualities and good attitudes students already have and also those who are not good. This is important so that the next educational process is more focused and relevant to the needs of students. This understanding of innate attitudes is important so that educators do not get 
discouraged when the process of helping students does not go well because of innate attitudes that are not good. The initial ability of students in terms of character needs to be seen so that educators are not easily discouraged when the process is not smooth. By recognizing the initial state of students, character education will be more appropriate to the situation of students. There are students who quickly learn and develop character; some are not too fast, even difficult. This basic understanding is needed so that the choice of forms and methods of character education are appropriate to the circumstances of the students.

A study is conducted by Shobroh in 2013 on the Effect of Character Education on the Establishment of Honesty of MTs Ngalur Kulon Progo Students in Yogyakarta.

The results of the study prove that (1) the majority of students had religious characters of 5 "low" students and 49 "high" students, personality traits of 8 "low" students and 46 "high" students, an environment of 4 "low" students and 50 " high ", and nationalities of 13" low "students and 41" high "students so that it can be concluded that the majority of students have a high character compared to a low character. (2) The dependent variable namely honesty possessed by students is very high. (3) Each independent sub-variable that is religious character obtained by phi of 0.12 and the significance value of 0.38 , this means that there is no effect on student honesty. Personality character obtained by phi 0.41 and the significance value of 0.00 , means that there is an influence on student honesty. The character of the environment is obtained phi 0.15 and the significance value is 0.26 , meaning there is no influence on student honesty. National character is obtained phi 0.27 and the significance value is 0.05 , meaning there is a weak influence on the honesty of students. (4). Of the four independent subvariables only personality and nationality characters were found to have a significant effect on the honesty establishment of MTs N Galur students, indicating that honesty behaviour could be explained by personality and nationality characters in character education contributing $0.24 \quad(24 \%)$ and the remaining $76 \%$, student honesty is influenced by other sub-variables which are not included in this study.

Thus, education means an effort to help students to become more advanced character or character develops. For this educational process there are many methods and ways that can be used. The specialty of character education is that assistance to develop student character is planned systematically, not just randomly. The choice of character education methods needs to be adapted to the situation of students and also adapted to the model of the educational approach that is now being developed, which is studentcentered and not the educator. That means methods need to be chosen that enable students to wrestle and develop their character.

\section{RESEARCH METHOD}

\subsection{Research Approach}

The approach of the study employs a quantitative approach. This quantitative approach is a scientific approach because it has fulfilled scientific principles that are concrete/ empirical, objective, 
measurable, rational and systematic. This method is also called the discovery method, because with this method can be found and developed a variety of new science and technology. This approach is called quantitative because this research data in the form of numbers and analysis using statistics. There are several reasons for using a quantitative approach, including the following: If the problem which is the starting point of the research is clear (Sugiyono, 2015:7). Researchers want to get broad information from a population. The reason researchers use a quantitative approach is to test a theory related to the issues raised and to show the influence of preliminary data from psychological selection (X1) and foster officer counselling guidance (X2) on the successful establishment of the cultural character of policewomen school students $(\mathrm{Y})$.

\subsection{Operationalization of Variables}

Operationalization of variables, according to Suryabrata (2005:29-30) is a definition based on the nature of the defined things that can be observed. The operationalization of variables in research is an element of research related to the variables contained in the research titles or those included in the research paradigm in accordance with the results of the problem formulation. The operationalization of the variables of this study is as follows:

1) Preliminary Psychological Selection Data (X1) - the growth and development of a person in a certain different environment will show a pattern of behaviour that is typical of the environment earlier. In addition, various patterns of activities and learning can also affect a person's activities as seen from his behaviour that can be measured. The behaviour is an embodiment of aspects of cognitive, affective, and psychomotor development which then becomes a benchmark for the students of policewomen school to be treated according to their ability levels. By using the policewomen school Psychology Selection guidelines, the indicators for this variable are: Intelligence,

Personality, Preference, and Work Attitude.

2) Foster Officer counselling guidance (X2)-Prayitno et. al., (in Luddin, 2010:4) states that the indicators of guidance and counselling, i.e. accept yourself, get to know and accept the environment positively and dynamically, directing yourself effectively and productively in planning for a better life in the future.

3) Character of "Kebhayangkaraan" (Y) - the value of kebhayangkaraan character consists of twelve values, including: faith, loving the motherland, democratic, discipline, hard work, smart work, professional, simple, empathy, honest, impartial, model, and integrity.

\subsection{Population and Samples}

\subsubsection{Population}

One study certainly has limitations in presenting sources of information or research subjects. In addition, research whose results can be generalized certainly has a proportional sampling process so that the conclusions can be generalized. Sugiyono (2015:80) states that the population is a generalization area that 
consists of objects/subjects that have certain qualities and characteristics that are determined by researchers to study and draw conclusions.

\subsubsection{Samples}

The sample is determined by the researcher based on consideration of the problem, objectives, hypotheses, methods, and research instruments, in addition to consideration of time, energy, and funding. As explained above, the sample consists of research subjects (respondents) who are selected data sources from the results of the work of the sampling technique (sampling technique). The sampling method that the author will use is saturated sample that is $\mathrm{N}=\mathrm{n}$, because the population to be studied is small so the possibility to be taken entirely is very large for a sample of that population, by examining the entire population the research will be more valid because all are represented. This is expected to provide the real answers. So, based on this explanation, with a small population of 47 people, the total sample used is 47 people.

\subsection{Data Collection Techniques}

The data collection technique in this study is a questionnaire. Data collection tools in this study refer to the Likert Scale. Sugiyono (2010:93) states that the Likert Scale is used to measure the attitudes, opinions, and perceptions of a person or group of people about social phenomena. With a Likert Scale, the measured variables are translated into indicator variables. Then the indicator is used as a starting point for compiling instrument items which can be statements or questions. Each statement item distinguishes alternative answer choices that are arranged based on a Likert Scale with a range of five scales (1 to 5) that describe the level of conditions, namely certain categories that represent respondents' choice of answers. Then weighting is done on each alternative answer on each statement item chosen by the respondents, namely: Value 5 (Strongly Agree), Value 4

(Agree), Value 3 Doubtful), Value 2 (Disagree), and Value 1 (Strongly Disagree)

\subsection{Data Analysis Techniques}

\subsection{Normality Test,}

Data requirements test conducted by researchers is a normality test to find out whether the population data is normally distributed or not. Normality test is a test to measure whether the data has a normal distribution, so it can be used in parametric statistics. Sample normality test is intended to test whether or not the sample is normal. The test is held with a view to seeing whether or not the data to be analyzed is normal. The study uses the Kolmogorov-Smirnov parametric test technique.

\section{Hypothesis Test}

Multiple Regression Analysis, The process of data analysis in this study uses multiple linear regression analysis methods. Multiple linear regression is a method for studying an event that is affected by more than one variable. The equation of multiple linear regressions in this study is as follows:

$$
\mathrm{Y}=\alpha+\beta 1 \mathrm{X} 1+\beta 2 \mathrm{X} 2+\varepsilon(1)
$$

\section{Notes:}

Y: Variable character of kebhayangkaraan in the students of policewomen school $\alpha$ : Constants 
$\beta 1$ : Variable regression coefficient for initial psychological examination data $\mathrm{X} 1$ : Initial data variable of psychological examination

$\beta$ 2: Regression coefficient of foster officer counselling guidance variable $\mathrm{X} 2$ : Foster officer counselling variable $\varepsilon$ : Residual (other variables not examined in the study)

\section{RESULT}

\subsection{Description of Variables}

Description of the research variable contains an overall overview of the research variables relating to data collection obtained from respondents' answers to the questionnaire that has been distributed as a data collection tool. The general description in question is about the answers that have been chosen by respondents to the statements given in the whole questionnaire, so that from these answers can be described statistics of respondents' choice of answers to the statements contained in the questionnaire as an instrument for measuring variables used in this study. Descriptions of the variables presented in this study include the description of the character variables of kebhayangkangan, Foster officer counselling guidance and preliminary psychology data. From the results of the data conducted, it can be seen that all respondents filled out all statements on the questionnaire given. Then to find out the responses of respondents the researcher determined the criteria for interpreting the score and its intervals. The criteria consists of five, namely Very High, High, Medium, Low, and Very Low. Researchers use the interval interpretation of the score according to Ridwan (in Pramono, 2016:107), as seen in table 4.6 below:

\section{a) Descriptive Analysis of the Variable Character of Kebhayangkaraan in the students of policewomen school.}

From the results of data processing, it can be seen that all respondents from the results of data processing answered all statements given in the questionnaire of kebhayangkaraan characters to the students of policewomen school. Respondent's answer data related to these statements can be seen from the following table:

Tabel 1: Descriptive Analysis of the Variable Character of Kebhayangkaraan in the students of Policewomen School

\begin{tabular}{|c|c|c|}
\hline \multicolumn{1}{|c|}{ No } & Interval & Criteria \\
\hline 1 & $81 \%-100 \%$ & Very High \\
\hline 2 & $61 \%-80 \%$ & High \\
\hline 3 & $41 \%-60 \%$ & Moderate \\
\hline 4 & $21 \%-40 \%$ & Low \\
\hline
\end{tabular}

Source: Pramono, 2016

Table 2: Frequency Distribution of Cultural Characteristics to Policewomen School Students

\begin{tabular}{|c|c|c|c|c|}
\hline & Frequency & Percent & Valid Percent & Cumulative Percent \\
\hline $51-63$ & 15 & 31,9 & 31,9 & 31,9 \\
$64-76$ & 7 & 14,9 & 14,9 & 46,8 \\
$77-89$ & 8 & 17,0 & 17,0 & 63,8
\end{tabular}




\begin{tabular}{|cc|c|c|c|c|} 
Valid & $90-102$ & 12 & 25,5 & 25,5 & 89,4 \\
& $103-115$ & 4 & 8,5 & 8,5 & 97,9 \\
& $116-128$ & 1 & 2,1 & 2,1 & 100,0 \\
& Total & 47 & 100,0 & 100,0 & \\
\hline
\end{tabular}

Source : Output SPSS 19

Based on the frequency distribution of the score of kebhayangkaraan characters in policewomen school students in the table above, it is known that respondents who received scores in answering the questionnaire of kebhayangkaraan characters in policewomen school students were in the range of 51-63 with 15 respondents or $31.9 \%$. Or on average, the score of the policewomen school students' Abstinence Character variable is $78.47 / 30=2.61$, while the median is $79 / 30=2.63$, which means that the value of "Women's police school's" Abstinence Student Character is below the average level.

\section{b) Descriptive Analysis of Foster Officer counselling Guidance Variables}

From the results of data processing can be seen that all respondents answered all statements given in the Foster Officer counselling guidance questionnaire. The Foster Officer counselling questionnaire consisted of 12 statements given to 47 respondents. Respondent's answer data related to these statements can be seen in Table 3:

Table 3 Frequency Distribution of Foster Officer Counselling Guidance

\begin{tabular}{|r|r|r|r|r|}
\hline & Frequency & Percent & Valid Percent & Cumulative Percent \\
\hline Valid & 1 & 2,1 & 2,1 & 2,1 \\
& $21-26$ & 27,7 & 27,7 & 29,8 \\
$27-32$ & 13 & 31,9 & 31,9 & 61,7 \\
$33-38$ & 15 & 29,8 & 91,5 \\
$39-44$ & 14 & 29,8 & 8,5 & 100,0 \\
$45-50$ & 4 & 8,5 & 100,0 & \\
Total & 47 & 100,0 & & \\
\hline
\end{tabular}

Source : Output SPSS 19

Based on the frequency distribution of Foster Officer counselling score in the above table, it is known that the respondents who got the score in answering the Foster Officer counselling guidance questionnaire were mostly in the range of 33-38 with the number of respondents 15 people or $31.9 \%$. Or on average, the score of Foster Officer counselling guidance variable is $36.28 / 12$ $=3.02$, while the median is $36 / 12=3$, which means that the value of Foster Officer counselling guidance is above the average level. The calculation results show that Foster Officer counselling guidance is in the low category.

\section{c) Descriptive Analysis of Early Psychological Data Variables}

Based on data obtained from the results of psychograms, it is known that preliminary psychology data for policewomen school students that processing by the author.

Based on tabulation data obtained from the personnel section, it is known that most of the policewomen school students scored in good category, namely 27 people $(57.45 \%)$, while 20 people $(42.55 \%)$ of them had scores in the sufficient category. Although most of the preliminary psychology data scores are in the good category, the reality is that as long as the students study in women's police school are different. Like students of the policewomen school who get a score of "Good" in the dimension of intelligence, but when education actually 
violates by not doing exam questions. Likewise, policewomen school students who score in the good category, but still commit violations, such as sleeping during the teaching and learning processes, having difficulties to adapting, PU violations, even severe violations.

\section{2 Tests for Data Normality}

Testing for normality through the graph analysis probability plot can be seen from the point of spread around the diagonal line. Normality test results can be seen in Table 4:

Table 4 Test Normality

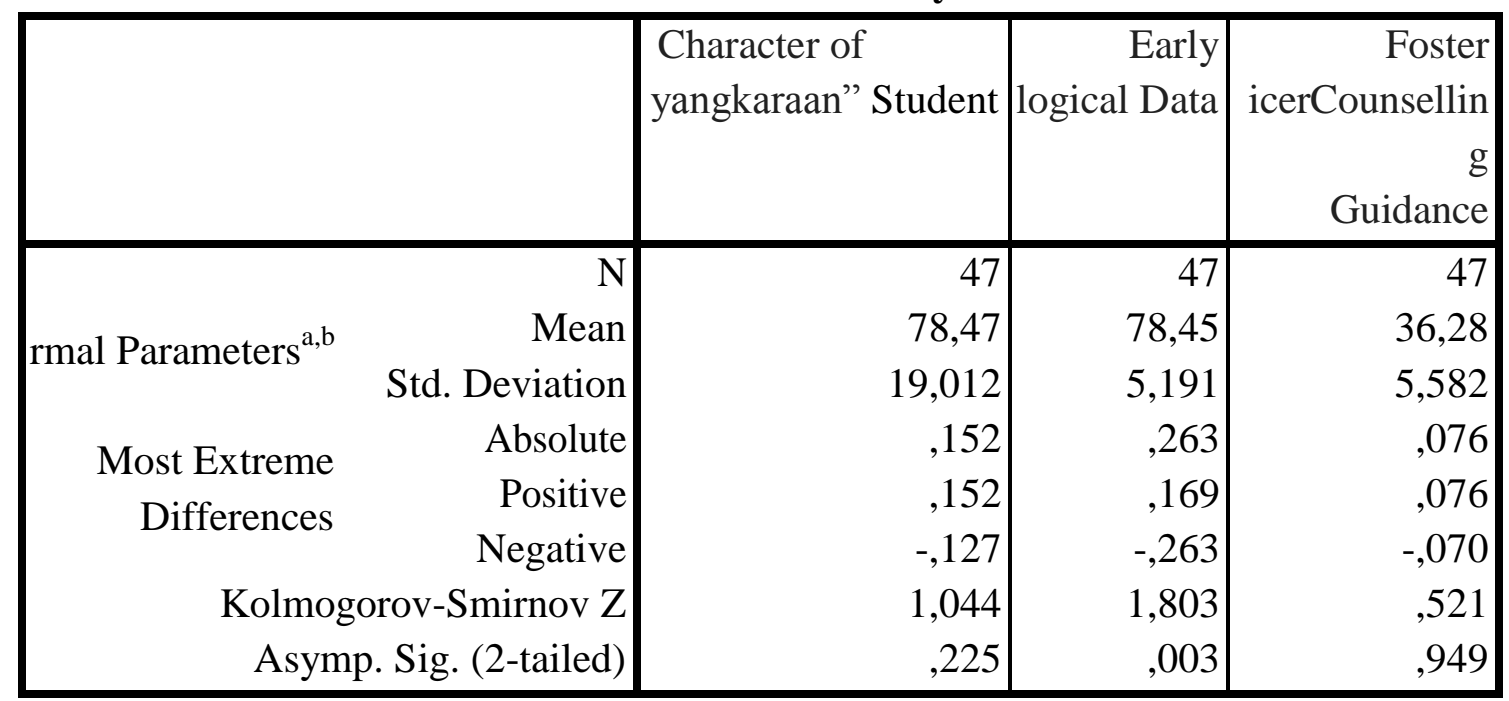

Output : Output SPSS 19

The normality test results in the table above show that:

The cultural character of policewomen school students is normally distributed with Kolmogorov-Smirnov value $\mathrm{Z}=$ $1.044 \mathrm{p}=0.225(\mathrm{p}>0.05)$. Initial psychology data were not normally distributed with Kolmogorov-Smirnov value $Z=1.803 \mathrm{p}=0.003(\mathrm{p}<0.05)$.

Counselling guidance is normally distributed with Kolmogorov-Smirnov value $\mathrm{Z}=0.521 \mathrm{p}=0.949(\mathrm{p}>0.05)$.

\subsection{Hyphothesis Testing}

\section{A. Multiple Linear Regression Effect}

Table 5. Results of Multiple Regression Analysis Effects of Early Psychology Data and Foster Officer Counselling Guidance on Character Student's on the Successful Establishment of the Characteristics of Kebhayangkaraan Policewomen School Students

\begin{tabular}{|r|r|r|r|r|r|}
\hline Model & \multicolumn{2}{|c|}{ standardized Coefficients } & $\begin{array}{r}\text { Standardized } \\
\text { Coefficients }\end{array}$ & Sig. \\
\cline { 2 - 5 } & $\mathrm{B}$ & Std. Error & Beta & & \\
\hline (Constant) & $-11,382$ & 39,337 & &,- 289 &, 774 \\
1 &, 097 &, 426 &, 027 &, 228 &, 820
\end{tabular}

of Preliminary Data Psychological Selection and Foster Officer counselling Guidance on the Successful Establishment of the Characteristics of Kebhayangkaraan policewomen school students

The results of the multiple linear regression effect of initial data on the results of psychological selection and guidance of Foster Officer counselling on the success of shaping the character of the policewomen school students' happiness can be seen as follows. 
oster Officer counselling Guidance

Source : Output SPSS 19

Based on Table 5, mathematical equations can also be made as follows:

$\hat{\mathrm{Y}}=0.027 \mathrm{X} 1+0.665 \mathrm{X} 2$

The regression coefficient value of the Early Psychology Data (X1) is 0.027. It shows that every increase in the initial data of psychological selection results, the character of the policewomen school students can increase by 0.027 or $2.7 \%$, assuming other independent variables (guidance Foster Officer counselling) remains of value.

The regression coefficient value of the foster officer counselling guidance variable (X2) was 0.665 . This shows that each increase in Foster Officer counselling guidance, the character of the policewomen school students' happiness can rise by 0.665 or $66.5 \%$, assuming the other independent variables (Preliminary Psychological Data) remain of value.
Based on the comparison of the value of $\beta X 1$ with $\beta X 2$ it can be seen that the coefficient value $\beta X 2>\beta X 1$, which means that the Foster Officer counselling variable has a more dominant influence on the character of the policewomen school students' happiness compared to the influence of preliminary psychology data.

\section{B. Coefficient of Determination}

To determine the percentage of the effect of the independent variable on the dependent variable the determinant coefficient is used as seen in the following table:

Table 6 Coefficient of Determination

\begin{tabular}{|c|c|c|c|}
\hline \multirow{2}{*}{ Model } & $\mathrm{R}$ & R Square & Adjusted R Square \\
\hline 1 &, $660 \mathrm{a}$ &, 435 &, 410 \\
\hline
\end{tabular}

Source : Output SPSS 19

The coefficient of determination is used to test the goodness-fit of the regression model. A value close to one means the variation in the ability of independent variables to provide almost all the information needed to predict the variation of the dependent variable (Ghozali, 2011:97). Table 6 shows that adjusted $\mathrm{R} 2$ is 0.410 . This shows that $41 \%$ of policewomen school students' cultural character variables can be explained by these two variables, namely preliminary psychology data and Foster Officer counselling guidance. Both of these variables are determinant variables of policewomen school students' cultural character variables, while the remaining $59 \%$ are explained by other variables outside the research model, such as internal factors, including instincts or instincts, customs or habits, wills or wills, conscience, conscience, heredity or heredity, as well as external factors, including education and environmental factors (Gunawan, 2012:19).

\section{DISCUSSION}

\section{A. Analysis of the Effect of Preliminary Data on Psychological Selection Results on the Success of Forming the Characteristics of Policewomen School Students}

Based on the research results obtained $\beta=$ $0.027(p=0.820)$. This shows that each increase in the initial data from the 
results of psychological selection, the character of the policewomen school students' happiness can increase by 0.027 or $2.7 \%$, assuming the other independent variables (guidance of Foster Officer counselling) remain of value. The results also showed the value of $\mathrm{T}$ count $<\mathrm{TT}$ table $(0.228<2.015)$ with a significance level of 0.820 (greater than 0.05). This means that partially the preliminary psychological examination data (X1) does not affect the establishment of the policewomen school students (Y) student's kebhayankaraan character (Y) or even though the initial psychology data is improved, it cannot improve the policewomen school students' kebhayankaraan character.

Based on data collection through post- research interviews with one of the guiding officer in women's police school on 29 April 2017, it is known that there is a learning process from policewomen school students on various forms of psychological measurement and because the series of tests given each year are the same, preliminary psychology data from policewomen school students are less able to reflect the character of students in the form of dimensions of intelligence, personality, or accuracy of each student of policewomen school. The situation makes guiding officer always carry out evaluations in the educational process of policewomen school students, so that the establishment of a cultural character can be realized. The preliminary data of psychological examination is not absolute and primary as a benchmark for shaping the character of the policewomen school students' happiness.

The results of this study are also supported by the results of descriptive analysis of the initial psychology data variables. Based on the results of descriptive analysis, it is known that most of the policewomen school students scored in the good category, namely 27 people $(57.45 \%)$, while 20 people $(42.55 \%)$ of them had scores in the sufficient category. Although most of the preliminary psychology data scores are in the good category, the reality is that as long as the students study in women's police school are different. Like students of the policewomen school who get a score of "Good" in the dimension of intelligence, but when education actually violates by not doing exam questions. Likewise, policewomen school students who score in the good category, but still commit violations, such as sleeping during the learning teaching processes, having difficulties to adapting, PU violations, even severe violations. These results illustrate that the results of the initial psychological data examination are less able to predict the character of kebhayangkaraan, that students who score in the Good category, in fact have not been able to show the character of kebhayangkaraan seen from the violations committed.

The results of the study according to the author's analysis are due to the process of memorizing/memorizing or structured from policewomen school students on various forms of Psychology tests used in the initial selection, so the results given are not in accordance with the actual conditions of the policewomen school students. Psychologists should be able to be more intense in conducting the initial examination of policewomen school students, because the data from the psychological selection examination will be used as a reference in shaping the character of happiness during the policewomen school students undergoing education.

\section{B. Analysis of the Effect of Foster Officer counselling Guidance on the Success of Establishing the characteristics kebhayangkaraan of policewomen school students}

Based on the research results obtained $\beta$ $=0.665(\mathrm{p}=0.000)$. This shows that every increase in Foster Officer counselling guidance, the character of students' women's police school could increase by 0.665 or $66.5 \%$, assuming other independent variables (Preliminary Psychology Data) remains of value. Tcount > Table $(5,719>2,015)$ with a 
significance level of 0,000 (less than $0.05)$. This means that partially there is a positive and significant influence between foster officer guidance counselling caregivers (X2) on the establishment of the character of kebhayangkaraan of policewomen school students (Y). This is supported by the description of respondents 'data which shows that most of the respondents' description data shows that most or $76 \%$ can be percentage or the average Foster Officer in policewomen school is occupied by women. The nature of the woman who has patience in providing guidance has an effect on the openness of the policewomen school students to tell each problem experienced to caregivers, so that solutions can be found for these problems. Guidance and counselling provided by female caregivers can increasingly improve the establishment of the character of kebhayangkaraan to policewomen school students. In other words, if the Foster Officer counselling guidance variable is improved, then the character of kebhayangkaraan in policewomen school students will also increase.

The results of this study are in line with Article 59 of the Regulation of Polri Chief Number 20/2007 concerning Education Component Standards for Establishment Education and Development Education within Polri Education and Training Agency, that teaching staff of the agency must have some competencies according to the requirements. One of them is being able to carry out guidance and counselling. In the guidance of Foster Officer counselling, various problems experienced by policewomen school students will be identified, so that an effective solution can be found, so that these problems do not interfere with the education of policewomen school students. The ability of caregivers to provide guidance and counselling can make students focus on education and have a good character of kebhayangkaraan The results of this study are in line with the opinion expressed by Battistich (in Eliasa, 2015) that the position of education as an input of knowledge about morals and goodness to students, clearly becomes an important reference for the establishment of expected student character. And one of the educational programs arranged for that is Guidance and Counselling which aims to encourage the birth of students who behave well. Students who grow in a good character, then do things right and tend to have a purpose in life. An effective character education will be found in schools that allow all learners to show their potential to achieve very important goals. Guidance and counselling provided by caregivers to policewomen school students will be able to support the establishment of the policewomen school students' cultural character. That is because through guidance and counselling, policewomen school students will increasingly understand every form of good and right behaviour, and be able to reduce various forms of violations committed by policewomen school students. Article 10 of the Regulation of Polri Chief No. 2/2007 concerning Psychological Support in the Care Patterns of the Students of Polri states that the stages of handling problems for policewomen school students included the stages of diagnosis and treatment. At the diagnostic stage interviews, observation and documentation are carried out. In the event that the diagnosis results indicate that women's police school has problems in the mild and moderate category, the psychologist provides recommendations for caregivers to be able to provide guidance and counselling. Guidance and counselling by caregivers for students with "problem" Women's police school ", will be able to provide a perspective for students" Women's police school "that every problem can be overcome without having to take action on actions that do not reflect the character of kebhayangkaraan. Through the guidance of Foster Officer counselling, policewomen school students will increasingly be able to undergo the education process in women's police school without feeling burdened and in 
the end will be formed Policewomen who have the character of kebhayangkaraan. The results of this study are in line with previous research conducted by Megalia (2016) which shows that there is an influence in the implementation of Cognitive Behaviour Therapy (CBT) counselling with Self Control techniques in reducing aggressive behaviour. Cognitive Behaviour Therapy (CBT) counselling is a counselling approach based on conceptualization or understanding of each counselee, namely the counselee's specific beliefs and counselee's behaviour patterns. Cognitive-Behaviour Therapy (CBT) counselling is inviting the counselee to challenge wrong thoughts and emotions by presenting evidence that contradicts their beliefs about the problem at hand. Cognitive-Behaviour Therapy (CBT) is able to reduce the negative behaviour of the counselee. The process of guidance and counselling is based on the counselor's conceptualization or understanding of specific beliefs and behaviour patterns of the counselee. Guidance and counselling given to student's women's police school is able to help the problems that arise during policewomen school students undergoing education. Guidance and counselling given with a good approach will be able to shape the character of kebhayangkaraan in accordance with the goals to be achieved women's police school. The results of a descriptive analysis of the age level of caregivers in women's police school showed that $46.81 \%$ of the average caregivers in the women's police school Police had more than 40 years of age. The age of the Foster Officers determines the level of maturity that is owned and the response shown in providing counselling to policewomen school students. Maturity that has been formed when someone enters adulthood makes caregivers able to position themselves as good listeners and as a source of information for every problem faced by student's women's police school. Calmness and patience in providing guidance will further enhance the quality of behaviour of policewomen school students, so that policewomen school students can increasingly show the character of "kebhayangkaraan".

Based on the analysis it is also known that the majority of caregivers in women's police school have an education level of S1 $(44.68 \%)$ and high school $(46.81 \%)$. Different levels of education will affect the level of competency of the individual (Bloom, in Azwar, 2007: 60). Differences in the level of education owned by caregivers in women's police school will determine the ability possessed in completing each task which is his responsibility in providing guidance and counselling. A lower level of education will result in a lack of knowledge and skills in implementing guidance and counselling to policewomen school students. Conversely, the higher the level of education from caregivers, the more it will support the establishment of the cultural character of the policewomen school students, due to the more extensive knowledge possessed. Caregivers will also have a different perspective on the various problems of policewomen school students, and assume that these problems must be overcome and the goal of shaping the character of happiness will be achieved.

\section{Analysis of the Effect of Preliminary Data on Psychological Selection and Foster Officer Counselling Guidance on the Success of Forming the Characteristics of Policewomen School Students' Treasures}

Based on the results of the study note the simultaneous influence (together) of the initial data variables of psychological selection and Foster Officer counselling guidance on the successful establishment of the policewomen school students' happiness character seen from the results of the Ftest stating the $F$ number calculated between the initial data variables of the results of psychological selection and guidance Foster Officer counselling on the success variable of the establishment of the policewomen school 
students'happiness

character

characteristics with a significance value of 0,000 is smaller than the significance level of $5 \%$ or 0.05 , which means that simultaneously (together) the initial data variables of the results of psychological selection and Foster Officer counselling influence on the establishment of the women's police school student's cultural character.

The results of this study are in line with the opinion expressed by Rotal (2014), that the factors that influence character establishment are the presence of innate and environmental factors. These factors will shape the character of children both positive and negative characters. This depends on environmental factors where children live, because the environment is a very dominant factor in the establishment of children's character. A good environment will be able to shape the positive character of children, as well as a bad environment will form a negative character of children. The character of students can be improved if the neighborhood and school environment supports the improvement of student character. In women's police school education, counsellor is one part of women's police school student life. A series of assistance from counsellors to members of the policewomen school students to solve problems or topics that occur in general and actual terms, can help shape the character of happiness in the policewomen school students.

The results of this study are in line with previous studies conducted by Satryawati and Saniah (2012) which show that there is a positive relationship between the results of psychological testing with the placement of employees in the Samarinda State Polytechnic Office. Psychological testing is a psychological activity that uses certain psychological testing tools as a measurement tool (in the form of test questions) created by psychologists. This test aims to measure a person's conditions related to intellectual abilities, emotions, interests, talents, and personality. Psychological tests are used to measure the possibilities of various mental abilities and what supports them, including achievement and ability, personality, intelligence, or even neurological function. Psychological testing can be done in a variety of settings including recruitment in women's police school.

The results of psychological examinations from policewomen school students should be used as a basis for shaping the policewomen school students' cultural character. The results of this study are also in line with previous research conducted by Rotal (2014) which shows that group guidance services with sociodrama techniques can improve student character in manners with teachers and neatness in uniform. The role of group guidance services is to equip students with a variety of knowledge and understanding of various things that are useful for getting to know you, planning and developing patterns of life as students, family members, and society. The understanding gained through group guidance is used as a reference material to improve character education.

Based on the results of the study note that the magnitude of the influence of the initial data on the results of psychological selection is equal to $B=$ 0.027 ( $\mathrm{p}=0.820)$. These results indicate that the preliminary data from the results of psychological selection have a positive but not significant effect on the establishment of the women's police school student's cultural character. The magnitude of the influence of preliminary data on the results of psychological selection on the establishment of the policewomen school students' cultural character is $2.7 \%$.

Human resources/apparatus are factors that are very influential in an organization. Sutrisno (2009:3) states that human resource management is a strategic field of an organization. Human resource management must be seen as an extension of the traditional view of managing people effectively and for that requires knowledge of people and the ability to manage them. For the 
achievement of organizational goals, human resources have an important role. Therefore, to get competent human resources that are appropriate to the needs of the organization, psychological selection in accepting policewomen school students should be able to provide accurate data. Preliminary data from the results of psychological selection on policewomen school students can support the pattern of nurturing policewomen school students while undergoing education, so that the establishment of imaginary characters will be increasingly achieved.

As explained in Article 2 of the Regulation of Polri Chief No. 2/2007 concerning Psychological Support in the Care Patterns of Students of Polri that psychological support in care aims to assist in the establishment of mental personality through providing input, participating in psychological care activities, and dealing with problem students. Preliminary data from the results of psychological selection on policewomen school students are products of psychologists, namely Psychology graduates who have the competence to carry out diagnoses, prognoses, and treatments as an effort to solve psychopsychological problems. Preliminary data from the results of psychological selection on policewomen school students should be able to give "kebhayangkaraan" in accordance with the objectives to be achieved women's police school.

A description of the character of the policewomen school students, so that it can provide clues in the establishment of the policewomen school student's kebhayangakaraan character. However, in this study the preliminary data from the results of psychological selection on policewomen school students did not significantly influence the establishment of the policewomen school students' cultural characteristics. According to the author's analysis, this can be caused by the policewomen school students who have learned either in a patterned or structured way (by practicing) beforehand about psychological tests, so the results of psychological tests are less accurate and less able to provide a true picture of students of policewomen school. The existence of the learning process carried out by policewomen school students on these psychological tests results in the lack of influence of the initial data on the results of the examination of the establishment of the character of kebhayangkaraan. Based on descriptive analysis of aspects of the character kebhayangkaraan of the policewomen school students, the aspect of believing with the statement, that is, policewomen school students are diligent in worshiping "have the highest score. That means the policewomen school students have high faith in God the Almighty. Religious life becomes important in shaping the policewomen school students' cultural character, because with the religious basis in policewomen school students, they can form a policewoman responsible, trustworthy in their words or deeds. In addition, it can form a figure of policewomen who can work in accordance with the SOP, avoiding practices of fraud and indiscipline. That is because faith in God can make student's women's police school avoid negative things, as is the case with religious teachings. Based on descriptive analysis, the empathy aspect with statement number 19, namely policewomen school students is able to understand the colleague's sad romance has the lowest score. This means that student's women's police school lacks closeness with colleagues in women's police school, Empathy as the ability to understand the feelings of others is important in an interaction in women's police school. High empathy can strengthen the determination and hard work of policewomen school students because of a sense of togetherness and mutual ownership among policewomen school students.

Based on the results of the study note that the magnitude of the effect of Foster Officer counselling guidance on the successful establishment of the character of the policewomen school students' happiness is equal to $\beta=0.665$ $(p=0.000)$. These results indicate that 
caregiving counselling has a positive and significant effect on the establishment of the women's police school student's cultural character. The magnitude of the influence of Foster Officer counselling guidance on the establishment of the women's police school student's cultural character is $66.5 \%$. Luddin (2010:11-12) states that guidance and counselling is interpreted as giving advice, giving advice and talking with exchanging ideas. Through counselling guidance provided by caregivers, students will increasingly understand the problems faced, and together find a solution to these problems, thus supporting the establishment of the character of kebhayangkaraan in student's women's police school.

Based on the results of the study it was also known that the adjusted $\mathrm{R} 2$ value was 0.410 . This shows that $41 \%$ of the policewomen school students' cultural character variables can be explained by both variables, namely preliminary psychology data and Foster Officer counselling guidance, while the remaining $59 \%$ is explained by other variables outside the research model such as internal factors, including instincts or instincts, customs or habits, wills or wills, conscience or conscience, heredity or heredity, as well as external factors, including education and environmental factors (Gunawan, 2012: 19). Policewomen school students who think that the guidance and counselling of caregivers are able to increase their capacity will increasingly show the character of happiness. In addition, caregivers who also consider preliminary psychological examination data will have some form of description of the character of the women's police school student. In providing guidance and counselling, caregivers will be easier to handle and provide solutions to problems faced by policewomen school students.

\section{CONCLUSION}

By paying attention to the analysis and discussion of research findings that have been carried out, the conclusions obtained are the answers to the problems raised in this study as follows:

1) The character of "kebhayangkaraan" students women's police school is positively but not significantly influenced by the results of the preliminary data on psychological selection, the meaning of the initial data results of the psychological evaluation of the character of "kebhayangkaraan" cannot increase significantly this preliminary results because the psychological selection can be studied patterned and the final result of psychological selection data there is a tendency forced gets a " $\mathrm{C}$ " value even though it is given a " $\mathrm{K}$ and KS" value. Thus Hypothesis " 1 " is rejected. This is different from Head of Police Regulation No. 2 of 2007 and research by Satryawati and Saniah (2012).

2) The character of "kebhayangkaraan" is positively and significantly influenced by the guidance of Foster Officer counselling with a coefficient of $66.5 \%$ where the most dominant establishment is able to know the establishment of the most dominant is able to know the mood change with a coefficient of $34.1 \%$, meaning that if the Foster Officer counselling guidance is improved then the character of kebhayangkaraan can increase significantly this is in accordance with research Battistich (in Eliasa, 2015) and Megalia (2016). So thus Hypothesis 2 can be accepted.

3) The character of "kebhayangkaraan" is influenced by the guidance and counselling of caregivers and the results of the preliminary data on psychological selection simultaneously and significantly with a coefficient of $41 \%$, meaning that if the guidance and counselling of caregivers and the initial data of the results of psychological selection are improved, the character of kebhayangkaraan can increase significantly, this is in accordance with Rotal research results (2014) and 
Luddin (2010:11-12).

Thus,

Hypothesis " 3 " is accepted.

\section{IMPLICATION}

Based on the results of research conducted on the influence of preliminary data on the results of psychology selection and Foster Officer counselling guidance on the successful establishment of the women's police school students' cultural character, the suggestions made by the authors of the research conducted include:

1) It is recommended to caregivers women's police school in order to improve their competence by attending various trainings related to guidance and counselling, so that the quality of the guidance provided can be of higher quality and support the establishment of the women's police school student's cultural character.

2) It is recommended that each Regional police improve the quality of the initial psychological selection data through a change in the psychological test model that portrays personal character, so that the results of psychological selection can be accounted for and provide a true picture of prospective policewomen school students.

3) It is recommended to each Regional police that in conducting psychological tests, the test materials provided are not structured or patterned, meaning that every year psychological tests are not always the same. This is intended to prevent learning (practicing) of policewomen school students which results in inaccuracies in the initial psychological examination data. It is recommended to women's police school in preparing personnel who will become caregivers by providing training to improve the quality of Foster Officer guidance and counselling so that caregivers can help students to solve problems encountered during education at the school.

4) It is recommended to the school in order to further improve the quality of education provided to students, by paying more attention to the values of "kebhayangkaraan" in policewomen school students.

\section{REFERENCES:}

\section{A. Books/Journal:}

Anastasia dan Urbina, 1997, Tes Psikologi, Edisi Bahasa Indonesia, Jakarta: PT.Prenhalindo

Anwar Prabu Mangkunegara, 2013, Manajemen Sumber Daya Manusia Perusahaan, Bandung :PT Remaja Rosdakarya

Bibit Samad Irianto, 2006, Pemikiran Menuju Profesi Indonesian Police yang Profesional, Mandiri, Berwibawa dan Dicintai Rakyat, Jakarta: Restu Agung.

Deni Darmawan, 2014, Metode Penelitian Kuantitatif, Yogyakarta: Remaja Rosdakarya.

Danang Sunyoto, 2010, Uji Kuadrat dan Regresi Untuk Penelitian,

Yogyakarta:Graha Ilmu

Duwi Priyatno, 2012, Cara Kilat Belajar Analisis Data Dengan SPSS 20, Yogyakarta: Andi

, 2013, Analisis Korelasi, regresi dan Multivariate dengan SPSS, Yogyakarta: Gava Media

Doni Koesoema, 2007, Pendidikan Karakter, Strategi Mendidik Anak di Zaman Global, Jakarta: Grasindo

Driyarkara. 2006. Karya Lengkap Driyakara. Penyunting: A. Sudiarja, G. Budi Subanar, St. Sunardi, dan T. Sarkim. Jakarta: PT Gramedia Pustaka Utama.

Faustino Cordoso Gomes, 2003, Manajemen Sumber Daya Manusia, Yogyakarta: Andi 
Fred N Kerlinger, 2000, Asas-Asas Penelitian Behavioural. Yogyakarta: Gajah Mada Univ. Press

Gregory, 2004, Psychological Testing: History, Principles, and Applications, Boston: Allyn and Bacon

Hamdani, 2011. Strategi Belajar Mengajar, Bandung: Pustaka Setia.

Harsuko Riniwati, 2011, Mendongkrak Motivasi dan Kinerja Pendekatan Pemberdayaan SDM. UB Press, Malang

J. Supranto, 2003, Statistik Teori dan Aplikasi, Edisi Lima, Penerbit Erlangga, Jakarta

Ki Hadjar Dewantara, 2013, Ki Hadjar Dewantara: Pendidikan: Pemikiran, Konsepsi, Keteladanan, Sikap Merdeka. Yogyakarta: Majelis Luhur Persatuan Tamansiswa.

Masyhuri \& Zainuddin, 2008, Metodologi Penelitian: Pendekatan Praktis dan Aplikatif, Refika Aditama, Bandung

Murphy, K.R., \& Davidshofer, C.O., 2005, Psychological Testing, Principles and Applications sixth Edition , New Jersey: Pearson Education International

Paul Suparno, 2015, Pendidikan Karakter di Sekolah, Yogyakarta : Kanisius.

Pudi Rahardi, 2014, Hukum Kepolisian (Kemandirian Profesionalisme dan Reformasi Indonesian Police ), Jakarta

: Laksbang Grafika

Ronny R Nitibaskara, 2009, Polisi dan Korupsi , Jakarta: Rajawali Press

Sambas Ali Muhidin, 2011, Panduan Praktis Memahami Penelitian, Bandung: Pustaka Setia
Sugiyono. 2011. Metode Penelitian Kuantitatif kualitatif dan R\&D. Bandung: Alfabeta

Slameto, 2003, Belajar dan FaktorFaktor Yang Mempengaruhinya, Jakarta : PT.Rineka Cipta

Surya Dharma. 2005, Manajemen Kinerja, Jakarta: Pustaka Pelajar

Syofian Siregar, 2014, Metode Penelitian Kuantitatif Dilengkapi dengan Perbandingan Perhitungan Manual dan SPSS, Jakarta : Kencana Prenadamedia.

Thomas Lickona,2015, Character Matters, Jakarta: Bumi Aksara

Ulber Silalahi, 2012, Metode penelitian Sosial, Refika Aditama, Bandung

\section{B. Regulation:}

Peraturan KaIndonesian Police Nomor 2 Tahun 2007 Tentang Dukungan Psikologi Dalam Pola Pengasuhan Siswa Non-commissioned officer Kepolisian Negara Republik Indonesia

Peraturan Kepala Kepolisian Negara Republik Indonesia Nomor 20 Tahun 2007 Tentang Standar Komponen Pendidikan Untuk Pendidikan Pembentukan Dan Pendidikan Pengembangan Di Lingkungan Lembaga Pendidikan Dan Pelatihan Kepolisian Negara Republik Indonesia

Peraturan Kepala Kepolisian Negara Republik Indonesia Nomor 14 Tahun 2015 Tentang Sistem Pendidikan Kepolisian Negara Republik Indonesia 